\title{
TGF $\beta I$ and PDGF AA override Collagen type I inhibition of proliferation in human liver connective tissue cells Alvaro T Geremias ${ }^{1}$, Marcelo A Carvalho ${ }^{2}$, Radovan Borojevic ${ }^{1,3}$ and Alvaro NA Monteiro*1
}

\begin{abstract}
Address: ${ }^{1}$ Departamento de Bioquímica, Instituto de Química, Universidade Federal do Rio de Janeiro, Rio de Janeiro 21949, Brazil, ${ }^{2}$ Laboratório de Metabolismo Macromolecular Firmino Torres de Castro, Instituto de Biofísica Carlos Chagas Filho, Universidade Federal do Rio de Janeiro, Rio de Janeiro 21941, Brazil and ${ }^{3}$ Departamento de Histologia e Embriologia, Instituto de Ciências Biomédicas, Universidade Federal do Rio de Janeiro, Rio de Janeiro 21941, Brazil

Email: Alvaro T Geremias - atgeremias@uol.com.br; Marcelo A Carvalho - carvalho@biof.ufrj.br; Radovan Borojevic - radovan@histo.ufri.br; Alvaro NA Monteiro* - monteian@moffitt.usf.edu

* Corresponding author
\end{abstract}

Published: 03 December 2004

BMC Gastroenterology 2004, 4:30 doi:10.1 I86/I47/-230X-4-30

This article is available from: http://www.biomedcentral.com/I47I-230X/4/30

C) 2004 Geremias et al; licensee BioMed Central Ltd.

This is an Open Access article distributed under the terms of the Creative Commons Attribution License (http://creativecommons.org/licenses/by/2.0), which permits unrestricted use, distribution, and reproduction in any medium, provided the original work is properly cited.
Received: 16 August 2004

Accepted: 03 December 2004

\begin{abstract}
Background: A marked expansion of the connective tissue population and an abnormal deposition of extracellular matrix proteins are hallmarks of chronic and acute injuries to liver tissue. Liver connective tissue cells, also called stellate cells, derived from fibrotic liver have been thoroughly characterized and correspond phenotypically to myofibroblasts. They are thought to derive from fat-storing Ito cells in the perisinusoidal space and acquire a contractile phenotype when activated by tissue injury. In the last few years it has become evident that several peptide growth factors such as PDGF AA and TGF- $\beta$ are involved in the development of fibrosis by modulating myofibroblast proliferation and collagen secretion. The fact that during the development of chronic fibrosis there is concomitant deposition of collagen, a known inhibitory factor, and sustained cell proliferation, raises the possibility that stellate cells from chronic liver fibrosis patients fail to respond to normal physiologic controls.
\end{abstract}

Methods: In this study we address whether cells from fibrotic liver patients respond to normal controls of proliferation. We compared cell proliferation of primary human liver connective tissue cells (LCTC) from patients with liver fibrosis and skin fibroblasts (SF) in the presence of collagens type I and IV; TGF- $\beta$, PDGF AA and combinations of collagen type I and TGF- $\beta$ or PDGF AA.

Results: Our results indicate that despite displaying normal contact and collagen-induced inhibition of proliferation LCTC respond more vigorously to lower concentrations of PDGF AA. In addition, we show that collagen type I synergizes with growth factors to promote mitogenesis of LCTC but not SF.

Conclusions: The synergistic interaction of growth factors and extracellular matrix proteins may underlie the development of chronic liver fibrosis. 


\section{Background}

In normal liver, connective tissue cells are rare and mostly restricted to the periportal and pericentrovenular spaces and to the Glisson's capsule. A minor population of connective tissue cells is present inside the hepatic lobule, in the perisinusoidal space. They are known as hepatic stellate cells (HSC) and are considered to be one of the major contributors for fibrogenesis in liver [1]. Chronic and acute injuries to liver tissue induce a marked expansion of the connective tissue cells and concomitantly an abnormal deposition of extracellular matrix proteins [2]. Extensive studies of experimental models and humans have shown that these cells are of the myofibroblast lineage, characterized by the expression of smooth muscle $\alpha$-actin [3-5]. In fact, there is now increasing evidence that are several populations of myofibroblasts in the diseased liver in addition to those derived from HSC [6,7]. The origin of these cells is still debated. In experimental models, it is considered that an acute liver injury is followed by activation and increase of stellate cells, while chronic injuries elicit activation of similar cells that can be either of lobular or periportal origin [7]. In humans, extensive primary periportal fibrosis such as schistosomal fibrosis was related to expansion of myofibroblasts originating from the portal vein wall [8], while in cirrhosis resident periportal connective tissue cells, as well as lobular stellate cells and pericentrovenular cells were reported to convert into myofibroblasts $[3,9,10]$. Independently of their origin, connective tissue cells of human fibrotic and cirrhotic liver tissues were shown to have homogeneous morphologic characteristics, as well as a specific growth patterns [11-15].

Recent studies on the mechanisms controlling connective tissue cell expansion and abnormal collagen deposition during liver fibrosis have shown that several peptide growth factors are involved in the development of fibrosis. Evidence from in vivo and in vitro studies indicated that TGF- $\beta$ has a relevant role in the development of fibrosis, being a potent regulator of proliferation and of extracellular matrix protein synthesis [16-18]. TGF- $\beta$ is highly expressed in fibrotic regions and overexpression of TGF- $\beta$ in animal models results in fibrosis $[18,19]$. Conversely, TGF- $\beta$ antagonists can prevent experimentally induced fibrosis [20-22]. PDGF AA was shown to have a pivotal role in controls of normal and pathologic proliferation of two myofibroblastic cell lineages: mesangial cells in kidney and alveolar smooth muscle cells in lungs $[23,24]$.

On the other hand, it has also been demonstrated in vitro that the extracellular matrix can in its turn modulate cellular responses to peptide growth factors [25]. In vitro, fibroblast proliferation can be regulated by the presence of collagen type I. It has been suggested that collagen induces a quiescent state by decreasing the responsiveness to different growth factors $[26,27]$. An increase in cell density is also known to inhibit fibroblast proliferation in vitro. During the development of chronic fibrosis there is concomitant deposition of collagen and sustained cell proliferation, raising the possibility that liver connective tissue cells (LCTC) from chronic liver fibrosis patients fail to respond to normal physiologic controls.

In this study we addressed the question of whether cells from fibrotic liver patients respond to normal physiologic controls of proliferation. We compared the behavior of primary human LCTC from patients with liver fibrosis with skin fibroblasts (SF). We compared cell proliferation in the presence of collagen types I and IV, of TGF- $\beta$ and PDGF AA, and in combinations of collagen type $I$ and TGF- $\beta$ or PDGF AA. Our results indicate that LCTC respond more vigorously to lower concentrations of peptide growth factors than SF. Interestingly, collagen type I synergizes with the growth factors tested in promoting mitogenesis of LCTC but not of SF. We believe that this mechanism may underlie the development of chronic liver fibrosis.

\section{Methods \\ Cell lines}

Liver tissue fragments and skin biopsies were obtained through collaboration with the University Hospital, Department of Surgery, Federal University of Rio de Janeiro (O.M. Vieira, M.D.). An informed consent was obtained from every patient, and the study was conducted in agreement with the ethical guidelines of the Federal University of Rio de Janeiro. Diagnoses were given by the pathological anatomy service of the hospital. All surgical liver biopsies were obtained for diagnostic purposes during spleno-renal or porto-caval anastomosis. Skin fibroblasts were obtained from the mid-abdominal incision performed for the surgery. We studied six primary normal SF lines and ten primary LCTC lines derived from patients with schistosomal fibrosis or alcoholic cirrhosis.

Biopsies were collected and brought to the laboratory in chilled Dulbecco's modified Eagle's medium (DMEM) (Sigma, St. Lois, MO) with 10\% fresh human serum and $60 \mu \mathrm{g} / \mathrm{ml}$ of gentamicin (Schering, Rio de Janeiro, Brazil). They were cut into pieces of approximately $1 \mathrm{~mm}^{3}$, washed in fresh medium and plated, 6 or 9 pieces per 25 $\mathrm{cm}^{2}$ flask. They were maintained in DMEM supplemented with $4 \mathrm{~g} /$ liter HEPES and 10\% fresh human serum, at $37^{\circ} \mathrm{C}$ in a humid incubator with $5 \% \mathrm{CO}_{2}, 95 \%$ air. All the cultures used in this study were finite cell lines derived from the primary cultures described above, and were discarded before the 10th passage.

LCTC have been described in detail previously, and compared to skin fibroblasts and vascular smooth muscle cells 
$[12,13,15]$. They were characterized by electron microscopy, immunofluorescence, morphology and proliferation in culture and ability to contract a collagen matrix. These established primary cell cultures are homogeneous in terms of production of smooth muscle $\alpha$-actin, fibronectin, collagen I and III, and elements of the basement membrane such as collagen IV and laminin $[12,13,15]$. Hence, they can be phenotypically characterized as myofibroblasts and different from fibroblasts or smooth muscle cells.

\section{Serum and growth factors}

Fresh human citrated plasma was obtained from the hemotherapy service of the Hospital dos Servidores do Estado (Rio de Janeiro, Brazil). Plasma was coagulated with calcium and sera from several patients were pooled. Human TGF- $\beta 1$ and human recombinant PDGF-AA were purchased from Sigma Chemical Company, St Louis, MO. TGF- $\beta 1$ was activated by incubation in bovine serum albumin $1 \mathrm{mg} / \mathrm{ml}$ and $4 \mathrm{mM} \mathrm{HCl}$.

\section{Preparation of collagen coated dishes}

One hundred $\mu \mathrm{l}$ of solutions with varying concentrations of collagen type I (rat tail tendon collagen, prepared in our laboratory as previously described [13]) or collagen type IV (Sigma) were dispensed onto a 12-well or a 96well plate and dried under a laminar flow for $24 \mathrm{hr}$ at room temperature. This procedure allowed us to control for the exact amount of collagen added to each plate. The plates used were freshly prepared and were washed three times in serum free medium.

\section{Proliferation}

Cell proliferation was assayed by cell counting and $\left[\mathrm{H}^{3}\right]$ thymidine incorporation. These methods correlated well with autoradiography results in previous studies [15]. For the experiments to assay contact inhibition of proliferation, approximately $1 \times 10^{3}$ cells $/ \mathrm{cm}^{2}$ were plated. Each day, during a period of 8 days, cells were trypsinized and counted in a hemocytometer and medium was changed every two days. To assay the proliferative response induced by growth factors and extracellular matrix proteins cells were trypsinized and plated at a concentration of $5 \times 10^{3}$ and allowed to adhere for $2 \mathrm{hr}$ in DMEM with $10 \%$ serum. Then, cells were starved in serum-free medium for $18 \mathrm{hr}$ to synchronize the cell population. When testing for growth factors effects, serum-free medium was replaced by medium containing $1 \%$ serum, supplemented with the growth factors and $0.5 \mu \mathrm{Ci} / \mathrm{ml}$ $\left[\mathrm{H}^{3}\right]$-thymidine. When assessing the effect of extracellular matrix proteins, serum-free medium was replaced by medium containing 10\% serum. Cells were collected 24 or $32 \mathrm{hr}$ after the stimulus and lysed in $10 \mathrm{~N} \mathrm{NaOH}$. The trichloroacetic acid precipitable material was then spotted on a filter and counted on a scintillation counter.

\section{Kinetics of thymidine incorporation}

Cells were plated at a concentration of $2.5 \times 10^{3}$ per well $\left(0.5 \mathrm{~cm}^{2}\right)$ in 96 well plates in DMEM with $10 \%$ serum. Cells were allowed to adhere and spread for two hr. Medium was then replaced with serum-free medium for $24 \mathrm{hr}$. Subsequently, cells were incubated in different media containing $1 \%$ serum and growth factors. $\left[\mathrm{H}^{3}\right]$-thymidine $(1 \mu \mathrm{Ci} / \mathrm{ml})$ was added at $6,24,32$ and $40 \mathrm{hr}$ and incubated for $2 \mathrm{hr}$. Cells were harvested and processed as described above.

\section{Adhesion and recovery}

To determine cell adhesion on different substrata plates were prepared with $0.3 \mathrm{mg} / \mathrm{ml}$ collagen type I or IV. Cells were plated on each substratum and the supernatant was removed at $0,10,20,40$ and $60 \mathrm{~min}$ and the cells remaining in suspension counted in a hemocytometer. To determine cell recovery, cells plated after 2 hr were trypsinized and counted.

\section{Statistical analysis}

Difference between the means of various subgroups was assessed using the Mann-Whitney U-test.

\section{Results}

Chronic liver fibrosis is characterized by abnormal proliferation of connective tissue cells. Therefore, we hypothesized that connective tissue cells from fibrotic lesions have lost normal proliferation controls. By using a series of primary connective tissue cell lines from skin and from fibrotic livers, we investigated several parameters of cell growth in vitro in order to identify potential mechanisms to explain the excessive proliferation of LCTC during fibrosis. We observed no differences among the cell lines obtained from patients with schistosomal fibrosis or alcoholic cirrhosis, and all the studied primary LCTC lines were included in a single experimental series. We established and characterized 16 primary human cell lines. The experiments performed were done at or before the tenth passage and every experiment was performed with at least two cell lines from each type (LCTC or SF) isolated from different individuals.

\section{Contact inhibition of proliferation}

To assess whether connective tissue cells from fibrotic livers (LCTC) and normal skin fibroblasts (SF) responded to contact inhibition of proliferation, we measured cell proliferation during eight days. Both LCTC and SF showed a comparable pattern of growth and reached a plateau at a similar cell density (Figure 1A,1B). Reproducibly, LCTC declined in number after reaching a maximal density (Figure $1 \mathrm{~B}$, day 8 ). To confirm these results, we measured $\left[\mathrm{H}^{3}\right]$-thymidine incorporation in various cell densities (Figure 1C). Both LCTC and SF showed maximum $\left[\mathrm{H}^{3}\right]$ thymidine incorporation at the same cell density $\left(1 \times 10^{4} /\right.$ 
A

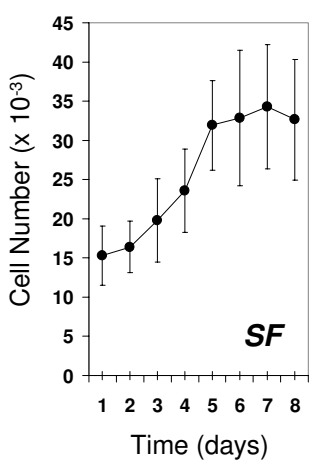

B

C

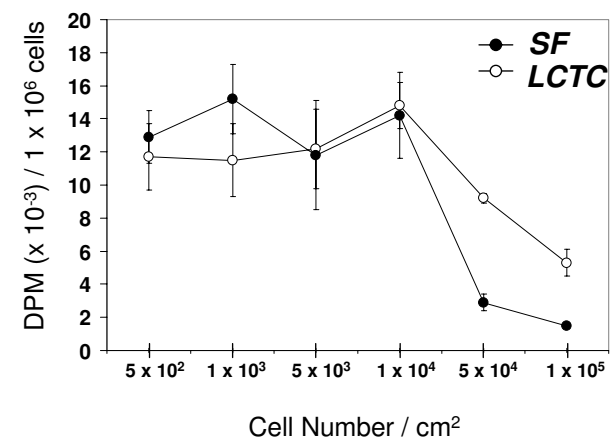

Figure I

Contact inhibition of proliferation. A. Proliferation of normal human skin fibroblasts (SF) in vitro. B. Proliferation of human liver connective tissue cells (LCTC). Cells were plated at I $\times 10^{3}$ cells $/ \mathrm{cm}^{2}$. Each day, during a period of 8 days, cells were trypsinized and counted in a hemocytometer $(n=3)$. Medium containing $10 \%$ serum was replaced every two days. C. $\left[\mathrm{H}^{3}\right]$-Thymidine incorporation in SF and LCTC at increasing cell density $(n=4)$.

$\mathrm{cm}^{2}$ ) and a marked decline at higher densities. We also examined the response of both cell types to increasing concentrations of fresh human serum. Both SF and LCTC reached maximum proliferation, as measured by $\left[\mathrm{H}^{3}\right]-$ thymidine incorporation at $20 \%$ serum (not shown). In conclusion, primary SF and LCTC were similarly responsive to normal contact inhibition of proliferation and serum concentration, although SF seemed to respond more efficiently to contact inhibition.

\section{The effects of extracellular matrix}

Despite the abnormal deposition of extracellular matrix in chronic fibrotic livers, LCTC continuously proliferate suggesting that these cells are not responsive to normal inhibition of proliferation by collagen I. To determine the influence of the extracellular matrix on LCTC, we analyzed DNA synthesis in the presence of collagen type I and type IV, two major components of extracellular matrix in fibrotic livers. Collagen type I inhibited DNA synthesis in a dose-dependent manner, as measured by $\left[\mathrm{H}^{3}\right]$-thymidine incorporation in LCTC and SF (Figure 2A,2B). In SF, $\left[\mathrm{H}^{3}\right]$-thymidine incorporation at the highest collagen concentration was approximately $30 \%$ of the control, suggesting that this cell type is more susceptible to collagenmediated inhibition of proliferation. However, the level of the inhibition was variable among the studied patients, and a less marked reduction, ( $\sim 50 \%)$ was observed in SF derived from some of the studied cases (not shown). We did not observe any change in cell morphology dependent upon the substrate.

The question of whether the difference observed between collagen-coated and plastic plates resulted from an alteration in kinetics of cell cycle progression or to an actual block in DNA synthesis was addressed in the following experiment. After serum-mediated activation of quiescent cells, the cultures were pulsed with $\left[\mathrm{H}^{3}\right]$-thymidine for 2 $\mathrm{hr}$, at 6, 20, 26, 32 and $40 \mathrm{hr}$. $\left[\mathrm{H}^{3}\right]$-thymidine incorporation reached its peak at 32 hours after activation in control experiments (plated on plastic), and cells plated on collagen-coated plates did not show any delayed peak, demonstrating that the effect of collagen was not delaying the progression of cell cycle but blocking DNA synthesis (Figure $2 \mathrm{C}$ ). These results indicate that LCTC are responsive to normal inhibition of proliferation mediated by collagen I.

Next, we asked whether collagen type IV could also influence the proliferation of the studied cells. Even at high concentrations $\left(90 \mu \mathrm{g} / \mathrm{cm}^{2}\right)$, collagen type IV did not induce any significant change on $\left[\mathrm{H}^{3}\right]$-thymidine incorporation in two LCTC cell lines, neither in two SF cell lines (not shown). Again, no difference in morphology was noted.

To rule out the possibility that the results were being masked by differential adhesion to collagen or differential cell recovery when measuring the $\left[\mathrm{H}^{3}\right]$-thymidine incorporation, we monitored cell adhesion on plastic, on collagen type I and on collagen type IV. Although by $10 \mathrm{~min}$ there were a significantly less cells attached on collagen IV, by $40 \mathrm{~min}$ the same number of cells had attached to the plates in all substrates (Figure 2C, right panel). These results rule out the possibility that lower $\left[\mathrm{H}^{3}\right]$-thymidine incorporation found in cells plated on collagen I was due to differential adhesion, since our experiments allowed 2 hr for attachment. We also counted cell numbers on the samples recovered for scintillation counting and found it to be comparable (Figure 2C, right panel), thus ruling out the possibility that the difference was due to differential recovery. Taken together these results indicate that LCTC 


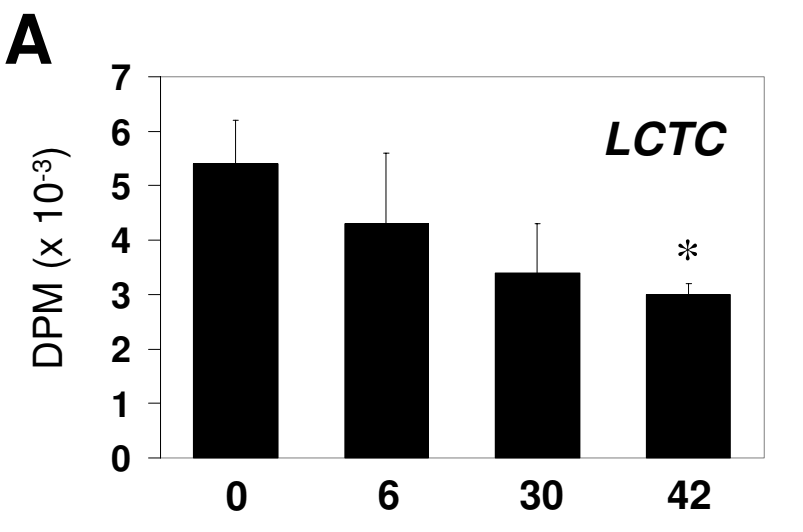

Collagen I concentration $\left(\mu \mathrm{g} / \mathrm{cm}^{2}\right)$
B

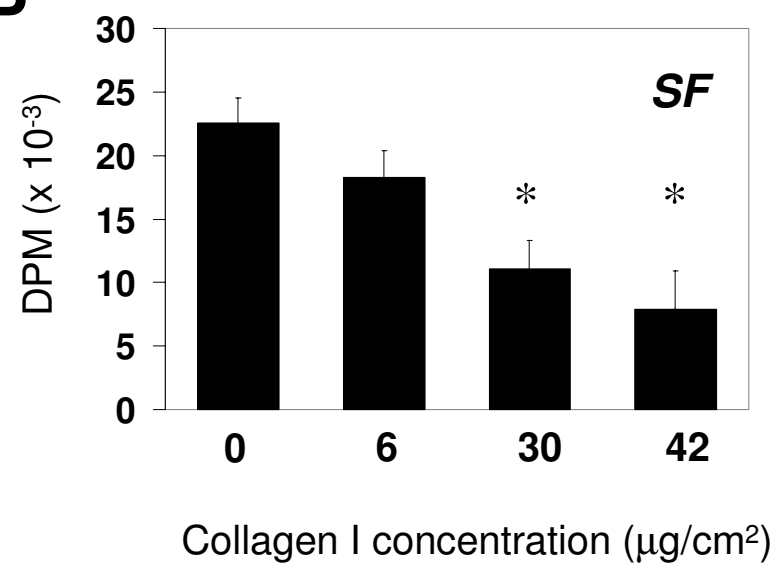

C

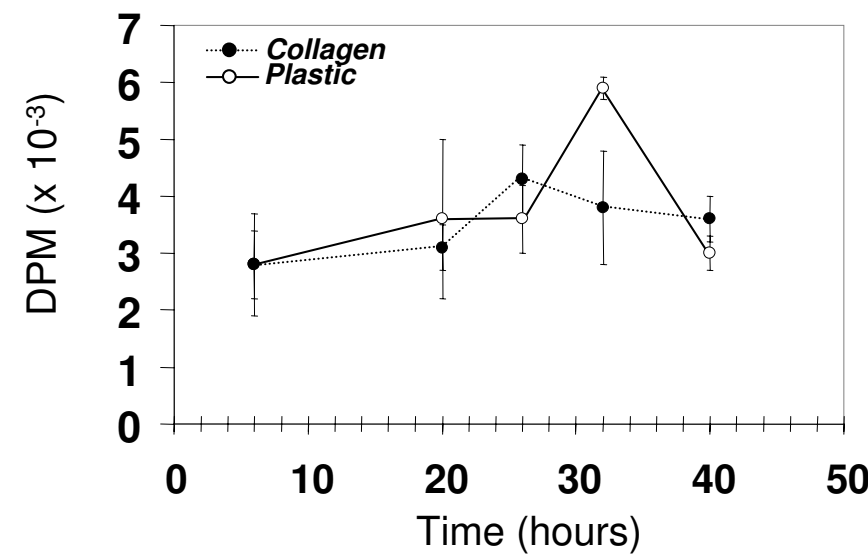

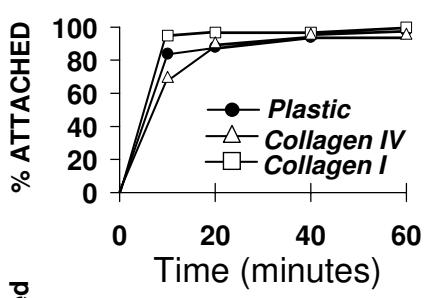

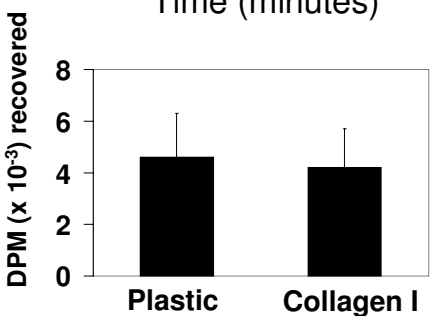

Figure 2

Collagen-mediated inhibition of proliferation. A. Cell proliferation of LCTC plated on increasing collagen concentration as measured by $\left[\mathrm{H}^{3}\right]$-Thymidine incorporation $(n=4)$. Note inhibition of incorporation in a dose-dependent manner. B. Cell proliferation of SF plated on increasing collagen concentration as measured by $\left[\mathrm{H}^{3}\right]$-Thymidine incorporation $(n=4)$. Note inhibition of incorporation in a dose-dependent manner. $\left(^{*}\right)$ denotes significant difference from control; $p \leq 0.05$. C. Left panel. Kinetics of DNA synthesis of LCTC comparing growth on plastic (empty circles) and on collagen (filled circles) ( $n=4)$. Right panel, top. Adhesion of cells plated on plastic (filled circles), collagen IV (empty triangles) and collagen I (empty squares) ( $n=3$ ). Right panel, bottom. Recovery of cells from plastic or collagen I $(n=4)$.

are responsive to normal inhibition of proliferation mediated by collagen I in a manner similar to that of normal SF.

\section{Effects of PDGF AA and TGF- $\beta$ on proliferation}

To investigate the effects of PDGF AA we starved cells for $18 \mathrm{hr}$ and stimulated them with increasing concentrations of PDGF AA. As shown in Figure 3A, LCTC were more sensitive to lower concentrations of the growth factor $(5,10$ and $20 \mathrm{ng} / \mathrm{ml}$ ), reaching a peak at $10 \mathrm{ng} / \mathrm{ml}$. Although reaching the same level of stimulation at $40 \mathrm{ng} / \mathrm{ml}$, SF were less sensitive to PDGF AA at lower concentrations. PDGF AA did not affect timing of cell cycle progression, since cells in the presence and in the absence of PDGF AA displayed a peak of [ $\left.\mathrm{H}^{3}\right]$-thymidine incorporation at $26 \mathrm{hr}$ after release in medium containing serum and factors (results not shown). In conclusion, LCTC appear to be more sensitive to lower concentrations of PDGF AA. 
A

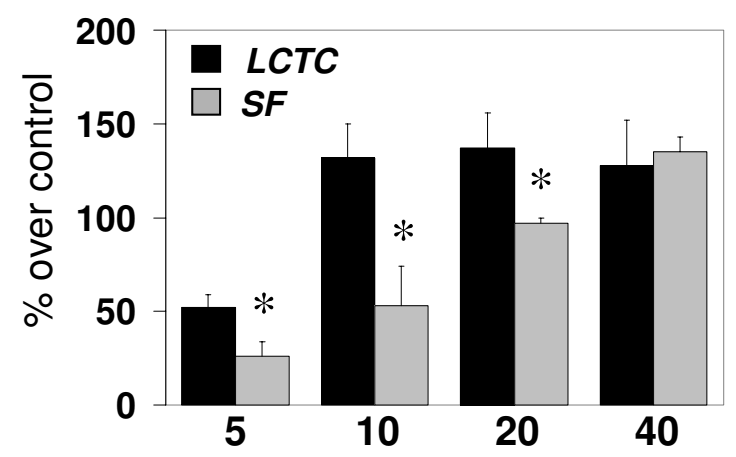

PDGF AA concentration ( $\mathrm{ng} / \mathrm{ml})$

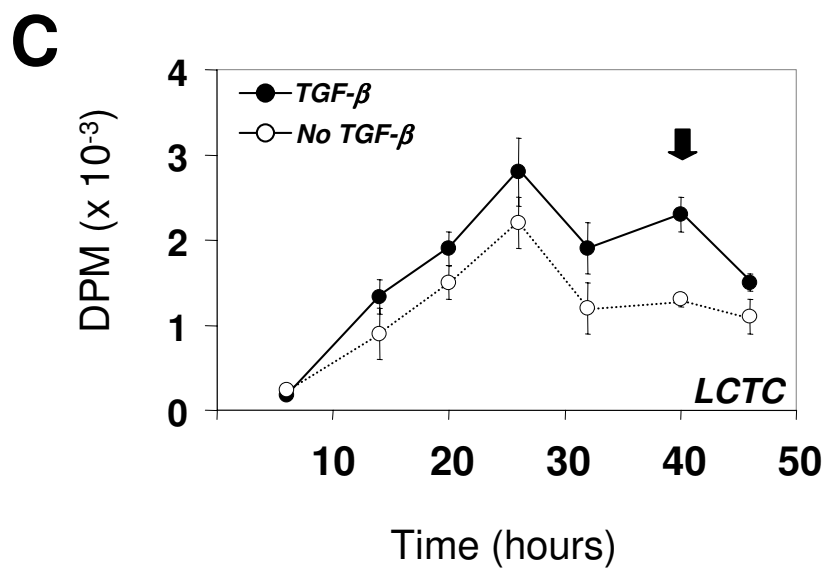

B

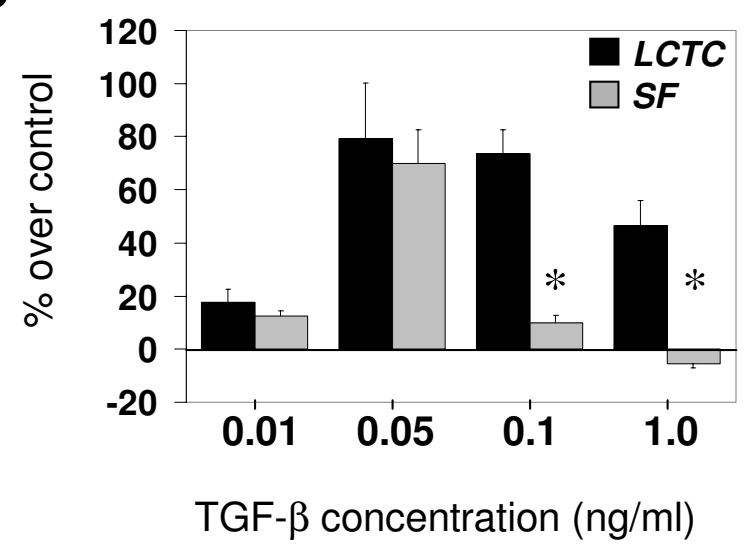

D

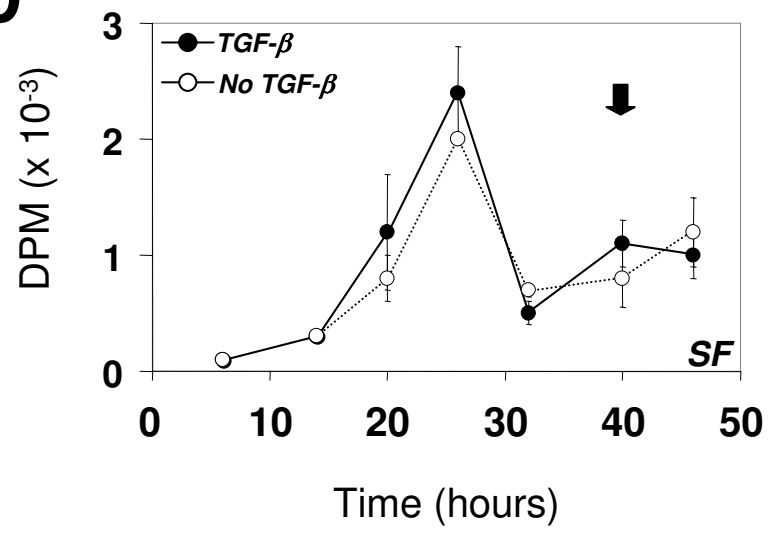

Figure 3

Mitogenic effects of PDGF AA and TGF- $\beta$ on SF and LCTC. A. Effect of increasing PDGF AA concentrations on growth of LCTC (black bars) and SF (gray bars) $(n=4)$. B. Effect of increasing concentrations of TGF- $\beta$ on growth of LCTC (black bars) and SF (gray bars) $(n=4)$. (*) denotes significant difference between SF and LCTC; $p \leq 0.05$. C. Kinetics of DNA synthesis in LCTC as measured by $\left[\mathrm{H}^{3}\right]$-thymidine incorporation in the presence (filled circles) and absence (empty circles) of TGF- $\beta(n=4)$. Note second delayed peak of incorporation at $40 \mathrm{hr}$ (black arrow). D. Kinetics of DNA synthesis in SF as measured by $\left[\mathrm{H}^{3}\right]$-thymidine incorporation in the presence (filled circles) and absence (empty circles) of TGF- $\beta(n=4)$. Note the absence of the second delayed peak of incorporation at $40 \mathrm{hr}$ (black arrow).

To test the responsiveness of LCTC and SF to TGF- $\beta$, cells were starved overnight and stimulated with increasing concentrations of acid-activated TGF- $\beta$. In Figure 3B we note that at lower concentrations, stimulation of LCTC and SF is comparable. However, higher concentrations of TGF- $\beta(0.1 \mathrm{ng} / \mathrm{ml})$ seemed to be less effective in promoting mitogenesis of SF. Interestingly, at the highest concentration $(1 \mathrm{ng} / \mathrm{ml})$ TGF- $\beta$ was inhibitory to SF but still highly stimulatory for LCTC. When we analyzed the kinetics of thymidine incorporation during TGF- $\beta$ treatment
(Figure 3C,3D) we observed a second delayed peak of DNA synthesis at $40 \mathrm{hr}$ (Figure 3C and 3D, arrow). In smooth muscle cells this second delayed peak has been shown to be due to a PDGF AA autocrine loop [28]. While in LCTC the second peak was $85 \%$ of the first peak, in SF it was slightly under $50 \%$. These results indicate that TGF$\beta$ can induce a prolonged and strong induction of DNA synthesis in LCTC even at concentrations that are inhibitory for SF. In this set of experiments we were able to compare matched LCTC and SF from the same patient. Our 
A

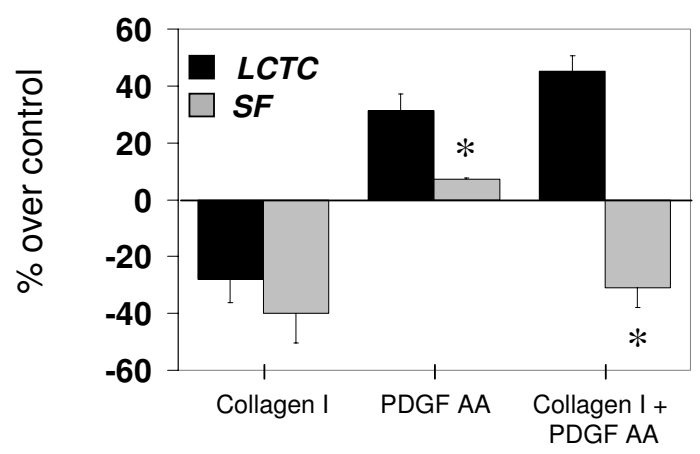

B

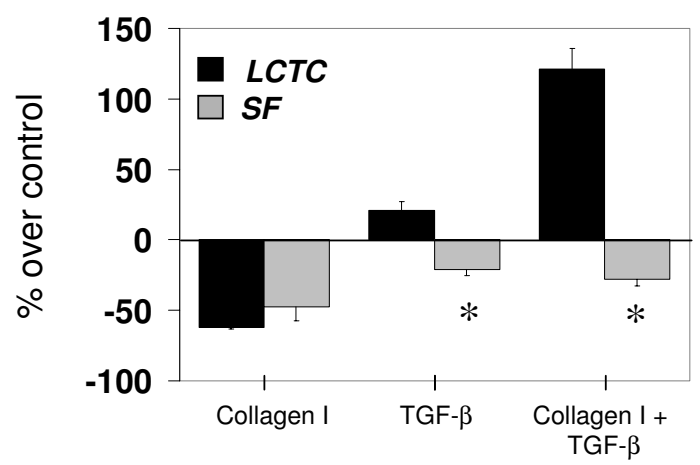

Figure 4

Interaction between peptide growth factors and extracellular matrix. A. Effects of PDGF AA on the growth of LCTC (black bars) and SF (gray bars) plated on collagen or plastic $(n=4)$. B. Effects of TGF- $\beta$ on the growth of LCTC (black bars) and SF (gray bars) plated on collagen or plastic $(n=3)$. $(*)$ denotes significant difference between SF and LCTC; $p \leq 0.05$.

results indicate that the observed differences between LCTC and SF are not due to individual variation or genetic background.

\section{Synergy of extracellular matrix and growth factors}

Next, we assessed the interplay between growth factors and the extracellular matrix on the stimulation of proliferation. We compared proliferation of cells cultured on collagen film using the highest inhibitory concentration (42 $\mu \mathrm{g} / \mathrm{cm}^{2}$; Figure 2) and cultured on plastic. Initially, we treated cells with $10 \mathrm{ng} / \mathrm{ml}$ of PDGF AA in the presence and absence of collagen after $24 \mathrm{hr}$ (Figure 4A). Both LCTC and SF were efficiently inhibited by collagen, in accordance with the experiments in Figure $2 \mathrm{~A}$ and $2 \mathrm{~B}$, performed with different cell lines. In the absence of collagen, PDGF AA stimulated proliferation comparable to that obtained in Figure 3A and 3B. These conditions provide an internal control to distinguish effects that are cell type-specific from individual variations. Surprisingly, PDGF AA was able to override the collagen-mediated inhibition only in LCTC and not in SF.

Next, cells were stimulated with TGF- $\beta$ (Figure 4B) and proliferation measured. Since there was a possibility that the autocrine loop could induce a late response, we assessed $\left[\mathrm{H}^{3}\right]$-thymidine incorporation at $40 \mathrm{hr}$. (Figure $4 \mathrm{~B})$. Collagen inhibited these cell lines as in previous experiments with LCTC and SF cell lines. TGF- $\beta$ alone had little effect on proliferation. However, similarly to the experiment with PDGF AA, TGF- $\beta$ was not only able to override the collagen-mediated inhibition but showed a synergistic effect only in LCTC. SF were not able to escape inhibition mediated by collagen.

\section{Discussion}

Injuries to liver tissue usually involve transient or longterm development of fibrosis. In acute injuries, fibrotic tissue is frequently reabsorbed and normal tissue architecture is restored. In cases when the primary agent or the secondary pathogenic mechanisms are persistent, the fibrotic reaction can be perpetuated causing a severe impairment of organ function [1]. It is therefore important to identify the factors that are involved in this perpetuation in order to devise more efficient preventive measures and therapies. However, there is a dearth of knowledge about the behavior of the human LCTC isolated from fibrotic livers. In fact, most studies done to date used LCTC cells from experimental models such as rats and mice and the few studies dealing with myofibroblasts from human liver derived the cells from normal tissue.

In order to evaluate the hypothesis that LCTC from fibrotic livers had lost control of proliferation we investigated their growth in tissue culture. Contact inhibition of proliferation is a characteristic of normal cells and is lost in neoplastic cell lines. Our results showed that LCTC respond normally to contact inhibition of proliferation. Collagen type I, which is the predominant extracellular matrix protein deposited during hepatic fibrogenesis [2], has been shown to be a potent inhibitor of mesenchymal cell proliferation $[26,29,30]$. Since the perpetuated proliferation of LCTC is a hallmark of chronic liver diseases, it was conceivable that these cells had lost normal collagenmediated inhibition. However, our results indicate that LCTC derived from fibrotic livers are responsive to collagen I to an extent comparable to normal skin fibroblasts. 
In addition, collagen IV a major component of basement membranes did not affect the growth of either cell type studied.

While recent evidence from rat vascular smooth muscle cells indicates that PDGF AA promotes only protein synthesis without activation of DNA synthesis [31], we demonstrate that PDGF AA is active as a mitogen for human LCTC. These results are in accordance with previous data using connective tissue cells derived from normal liver [32]. Interestingly, the same authors have found that in fibrotic livers there is marked increase in the expression of both PDGF $\alpha$ receptor and its ligand PDGF AA [33]. Taken together, these results strengthen the notion that PDGF$\mathrm{AA}$ is an important mediator of connective tissue expansion during liver fibrosis.

Although generally agreed to contribute to the fibrogenic process by upregulating expression of genes encoding extracellular matrix proteins, a role for TGF- $\beta$ in promoting mitogenesis has emerged in the last few years. TGF- $\beta$ displayed a bi-phasic curve with low concentrations stimulating and higher doses inhibiting the proliferation of SF. On the other hand, TGF- $\beta$ was a potent mitogenic stimulus for LCTC even at high concentrations. Interestingly, it has been shown that TGF- $\beta$ also stimulates an additional delayed growth response mediated by an autocrine loop of PDGF AA [28], which we observed only in LCTC.

One surprising outcome of this study was that not only the peptide growth factors tested were able to override the collagen-mediated inhibition, but that they were also able to synergize with the extracellular matrix. Since the collagen we used was a crude preparation from rat tail tendon we cannot rule out the possibility that the observed effect may depend on other associated proteins that are known to be accessory factors in promoting more efficient ligandbinding to the receptor. These results reinforce the notion that connective tissue cells can be therapeutically controlled using a strategy to inhibit the action of peptide growth factors.

It is well known that continuous presence of the injury agent determines the evolution of the disease, favoring its progression and perpetuation (establishment of a permanent scar tissue). On the other hand, it is largely unclear which are the other physiologic determinants for disease evolution. Genetic background is known to influence the development of hypertrophic cheloid skin scars as well as the outcome of schistosomal liver fibrosis [34]. In experiments in which we were able to use matched LCTC and SF from the same individual our results suggest that tissue origin was consistently more important than the genetic background, since LCTC behaved differently from the same-patient's SF but similarly to LCTC from different individuals.

\section{Conclusions}

The results obtained in this study using human primary liver connective tissue cells suggest a plausible scenario for the development of liver fibrosis. Stellate quiescent cells are triggered to proliferate by high molecular weight serum factors [15] and may be subjected to a positive autocrine and paracrine feedback loop of growth factor stimulation. Whereas under normal conditions connective tissue cells are kept under strict check by the extracellular matrix, PDGF AA and TGF- $\beta$ are capable of not only overriding the inhibitory effect caused by collagen type I on LCTC but also synergize to provide a stronger stimulus for proliferation. This interplay of extracellular signals may underlie the development of irreversible liver fibrosis.

\section{List of abbreviations}

HEPES: N-[2-Hydroxyethyl] piperazine-N'-[2-ethanesulfonic acid]; HSC: hepatic stellate cells; LCTC: liver connective tissue cells; SF: skin fibroblasts; PDGF: plateletderived growth factor; TGF- $\beta$ : transforming growth factor$\beta$.

\section{Competing interests}

The author(s) declare that they have no competing interests.

\section{Authors' contributions}

AG established primary cell line cultures, carried out the cell biological studies, participated in designing and interpreting the experiments. MC provided technical support for the cell cultures and participated in the writing of the manuscript. RB participated in the design of the study and in the interpretation of the results. AM established primary cultures, conceived of the study, and participated in its design and coordination. All authors read and approved the final manuscript.

\section{Acknowledgements}

This work was supported by the Conselho Nacional de Desenvolvimento Científico e Tecnológico (CNPq), Fundação de Amparo à Pesquisa do Rio de Janeiro (FAPERJ) and Financiadora de Estudos e Projetos (FINEP), Brazil.

\section{References}

I. Friedman SL: Molecular regulation of hepatic fibrosis, an integrated cellular response to tissue injury. J Biol Chem 2000, 275:2247-2250.

2. Gressner AM: The cell biology of liver fibrogenesis. Cell Tissue Res 1998, 292:447-452.

3. Rudolph R, McClure WJ, Woodward M: Contractile fibroblasts in chronic alcoholic cirrhosis. Gastroenterology 1979, 76:704-709.

4. Grimaud JA, Borojevic R: Chronic human schistosomiasis mansoni. Pathology of the Disse's space. Lab Invest 1977, 36:268-273.

5. Grimaud JA, Borojevic R: Myofibroblasts in hepatic schistosomal fibrosis. Experientia 1977, 33:890-892. 
6. Wells RG, Kruglov E, Dranoff JA: Autocrine release of TGF-beta by portal fibroblasts regulates cell growth. FEBS Lett 2004, 559:107-II0.

7. Knittel T, Kobold D, Piscaglia F, Saile B, Neubauer K, Mehde M, Timpl $R$, Ramadori G: Localization of liver myofibroblasts and hepatic stellate cells in normal and diseased rat livers: distinct roles of (myo-)fibroblast subpopulations in hepatic tissue repair. Histochem Cell Biol 1999, I I 2:387-40I.

8. Grimaud JA, Borojevic R: Portal fibrosis: intrahepatic portal vein pathology in chronic human schistosomiasis mansoni. J Submicrosc Cytol 1986, 1 8:783-793.

9. Li D, Friedman SL: Liver fibrogenesis and the role of hepatic stellate cells: new insights and prospects for therapy. J Gastroenterol Hepatol 1999, 14:618-633.

10. Tang L, Tanaka Y, Marumo F, Sato C: Phenotypic change in portal fibroblasts in biliary fibrosis. Liver 1994, I 4:76-82

II. Voss B, Rauterberg J, Pott G, Brehmer U, Allam S, Lehmann R, von Bassewitz DB: Nonparenchymal cells cultivated from explants of fibrotic liver resemble endothelial and smooth muscle cells from blood vessel walls. Hepatology 1982, 2:19-28.

12. Borojevic R, Vinhas SA, Monteiro AN, Domont GB, Zyngier FR, Grimaud JA: Liver connective tissue cells isolated from human schistosomal fibrosis or alcoholic cirrhosis represent a modified phenotype of smooth muscle cells. Biol Cell 1985, 53:23I-238.

13. Monteiro AN, Borojevic R: Interaction of human liver connective tissue cells, skin fibroblasts and smooth muscle cells with collagen gels. Hepatology 1987, 7:665-67I.

14. Monteiro AN, Borojevic R: In vitro formation of fibrous septa by liver connective tissue cells. In Vitro Cell Dev Biol 1987, 23:10-14.

15. Monteiro AN, Borojevic R: Complement-dependent induction of DNA synthesis and cell proliferation in human liver connective tissue cells in vitro. In Vitro Cell Dev Biol Anim 1995 3 I:I49-I55.

16. Border WA, Okuda S, Languino LR, Sporn MB, Ruoslahti E: Suppression of experimental glomerulonephritis by antiserum against transforming growth factor beta I. Nature 1990 346:37I-374.

17. Czaja MJ, Weiner FR, Flanders KC, Giambrone MA, Wind R, Biempica $L$, Zern MA: In vitro and in vivo association of transforming growth factor-beta I with hepatic fibrosis. J Cell Biol 1989, 108:2477-2482

18. Sanderson N, Factor V, Nagy P, Kopp J, Kondaiah P, Wakefield L, Roberts $A B$, Sporn MB, Thorgeirsson SS: Hepatic expression of mature transforming growth factor beta $I$ in transgenic mice results in multiple tissue lesions. Proc Natl Acad Sci U S A 1995, 92:2572-2576.

19. Bissell DM, Roulot D, George J: Transforming growth factor beta and the liver. Hepatology 200I, 34:859-867.

20. George J, Roulot D, Koteliansky VE, Bissell DM: In vivo inhibition of rat stellate cell activation by soluble transforming growth factor beta type II receptor: a potential new therapy for hepatic fibrosis. Proc Natl Acad Sci U S A 1999, 96:12719-12724.

21. Ueno H, Sakamoto T, Nakamura T, Qi Z, Astuchi N, Takeshita A, Shimizu K, Ohashi $\mathrm{H}$ : A soluble transforming growth factor beta receptor expressed in muscle prevents liver fibrogenesis and dysfunction in rats. Hum Gene Ther 2000, I I:33-42.

22. Dooley S, Hamzavi J, Breitkopf K, Wiercinska E, Said HM, Lorenzen J, Ten Dijke P, Gressner AM: Smad7 prevents activation of hepatic stellate cells and liver fibrosis in rats. Gastroenterology 2003, I 25: | 78-19|.

23. Betsholtz C, Raines EW: Platelet-derived growth factor: a key regulator of connective tissue cells in embryogenesis and pathogenesis. Kidney Int 1997, 5 I: I36 I-1369.

24. Bostrom $\mathrm{H}$, Willetts $\mathrm{K}$, Pekny $M$, Leveen $\mathrm{P}$, Lindahl $\mathrm{P}$, Hedstrand $\mathrm{H}$, Pekna M, Hellstrom M, Gebre-Medhin S, Schalling M, Nilsson M, Kurland S, Tornell J, Heath JK, Betsholtz C: PDGF-A signaling is a critical event in lung alveolar myofibroblast development and alveogenesis. Cell 1996, 85:863-873.

25. Davis $\mathrm{BH}$ : Transforming growth factor beta responsiveness is modulated by the extracellular collagen matrix during hepatic ito cell culture. J Cell Physiol 1988, 136:547-553.

26. Rhudy RW, McPherson JM: Influence of the extracellular matrix on the proliferative response of human skin fibroblasts to serum and purified platelet-derived growth factor. I Cell Physiol 1988, 137: 185-191.
27. Lin YC, Grinnell F: Decreased level of PDGF-stimulated receptor autophosphorylation by fibroblasts in mechanically relaxed collagen matrices. J Cell Biol 1993, I 22:663-672.

28. Battegay EJ, Raines EW, Seifert RA, Bowen-Pope DF, Ross R: TGFbeta induces bimodal proliferation of connective tissue cells via complex control of an autocrine PDGF loop. Cell 1990 63:5I5-524.

29. Yoshizato K, Taira T, Shioya N: Collagen-dependent growth suppression and changes in the shape of human dermal fibroblasts. Ann Plast Surg 1984, I3:9-14.

30. Schor SL: Cell proliferation and migration on collagen substrata in vitro. I Cell Sci 1980, 4I:159-175.

3I. Inui H, Kitami Y, Tani M, Kondo T, Inagami T: Differences in signal transduction between platelet-derived growth factor (PDGF) alpha and beta receptors in vascular smooth muscle cells. PDGF-BB is a potent mitogen, but PDGF-AA promotes only protein synthesis without activation of DNA synthesis [published erratum appears in J Biol Chem $1995 \mathrm{Apr}$ 28;270 (17): 1 0358]. J Biol Chem 1994, 269:30546-30552.

32. Pinzani M, Gentilini A, Caligiuri A, De Franco R, Pellegrini G, Milani S, Marra F, Gentilini P: Transforming growth factor-beta I regulates platelet-derived growth factor receptor beta subunit in human liver fat-storing cells. Hepatology 1995, $21: 232-239$.

33. Pinzani M, Milani S, Herbst H, DeFranco R, Grappone C, Gentilini A, Caligiuri A, Pellegrini G, Ngo DV, Romanelli RG, Gentilini P: Expression of platelet-derived growth factor and its receptors in normal human liver and during active hepatic fibrogenesis. Am J Pathol 1996, I48:785-800.

34. Dessein AJ, Hillaire $D$, elWali NE, Marquet $S$, Mohamed-Ali $Q$, Mirghani A, Henri S, Abdelhameed AA, Saeed OK, Magzoub MM, Abel $L$ : Severe hepatic fibrosis in Schistosoma mansoni infection is controlled by a major locus that is closely linked to the interferon-gamma receptor gene. Am J Hum Genet 1999, 65:709-72I.

\section{Pre-publication history}

The pre-publication history for this paper can be accessed here:

\section{http://www.biomedcentral.com/1471-230X/4/30/pre} pub
Publish with Bio Med Central and every scientist can read your work free of charge

"BioMed Central will be the most significant development for disseminating the results of biomedical research in our lifetime. "

Sir Paul Nurse, Cancer Research UK

Your research papers will be:

- available free of charge to the entire biomedical community

- peer reviewed and published immediately upon acceptance

- cited in PubMed and archived on PubMed Central

- yours - you keep the copyright

Submit your manuscript here:

http://www.biomedcentral.com/info/publishing_adv.asp
BiolMedcentral 